$\mathcal{H a l}: 15-21$

\title{
Penerapan strategi pembelajaran inquiri dalam meningkatkan motivasi belajar siswa pada pelajaran PPKn di kelas VIII SMP Pemda Rantauprapat Kabupaten Labuhanbatu Tahun Pelajaran 2017/2018
}

\author{
BUDI WINATA HASIBUAN \\ Dosen Program studi PPKn STKIP Labuhanbatu \\ Email: budiwinata.hasibuan@gmail.com
}

\begin{abstract}
ABSTRAK
Latar belakang penelitian ini adalah Pelajaran PPKn sangat penting untuk diajarkan kepada siswa. Namun kenyataanya pembelajaran PPKn kurang disukai siswa sekolah karena banyak memuat konsep atau topik yang abstrak, yang sulit dipelajari oleh siswa. Rendahnya nilai ujian semester siswa kelas VIII SMP Pemda Rantauprapat pada pelajaran PPKn Guru hanya menggunakan metode ceramah yang kurang mengajak siswa untuk aktif dalam pembelajaran. Kurangnya motivasi belajar siswa dalam belajar PPKn di kelas sehingga membuat hasil belajar siswa rendah. Tujuan penelitian ini adalah Untuk mengetahui penerapan strategi pembelajaran Inquiri dalam meningkatkan motivasi belajar PPKn siswa di kelas VIII SMP Pemda Rantauprapat. Pada penelitian ini peneliti menggunakan jenis penelitian tindakan kelas (PTK) yang mengarah kepada penggunaan strategi pembelajaran inquiri (belajar penemuan) untuk meningkatkan motivasi belajar siswa pada pelajaran PPKn di kelas VIII SMP Pemda Rantauprapat Kabupaten Labuhanbatu. Hasil Penelitian menunjukkan bahwa pada siklus I motivasi belajar siswa adalah dengan menggunakan strategi pembelajara inquiri ini motivasi belajar siswa mengalami perubahan. Motivasi belajar siswa yang rendah 20\%, motivasi belajar siswa sedang 53\% dan motivasi belajar siswa yang tinggi hanya 28\%. Pada siklus II didapat motivasi belajar siswa semakin meningkat. Motivasi belajar siswa yang rendah sebesar 5\%, motivasi belajar siswa yang sedang sebesar $10 \%$ dan motivasi belajar siswa tinggi sebesar $85 \%$.
\end{abstract}

Keyword: Motivasi Belajar, Strategi Inquiri, PPKn

PENDAHULUAN

Tujuan PPKn adalah untuk membentuk watak atau karakteristik warga negara yang baik. Sedangkan tujuan pembelajaran mata pelajaran PPKn, adalah untuk menjadikan siswa mampu berpikir secara kritis, rasional, dan kreatif dalam menanggapi persoalan hidup maupun isu kewarganegaraan di negaranya.
Berdasarkan tujuan tersebut diatas, maka materi dalam pembelajaran PPKn perlu diperjelas penyampaiannya karena menyangkut beberapa materi yang akan diperkenalkan pada siswa dan harus dipahami siswa seperti Pesatuan dan Kesatuan, Norma Hukum dan Peraturan, HAM, Kebutuhan warga Negara, Konstitusi Negara, Kekuasaan Politik, Kedudukan 
Pancasila, dan Globalisasi. Oleh karena itu merupakan kewajiban gurulah menanamkan materi ini pada siswa agar siswa mempunyai bekal mengenal negara kesatuan Republik Indonesia.

Pada hakikatnya proses pembelajaran adalah suatu kegiatan rutin yang dilakukan di setiap sekolah. Di dalam proses pembelajaran biasanya yang terlibat adalah guru dan siswa. Guru dan siswa berinteraksi menciptakan proses pembelajaran pada setiap materi pelajaran yang bertujuan agar siswa dapat memahami materi pelajaran dan meningkatkan hasil belajar siswa. Kegiatan pembelajaran merupakan proses komunikasi dua arah yang dilakukan oleh guru dan siswa. Selama proses pembelajaran, mental siswa dilibatkan secara maksimal yaitu siswa tidak hanya mendengar dan mencatat melainkan juga harus berpikir dan berkarya, sehingga pada proses pembelajaran akan terbangun suasana dialogis. Tetapi kenyataannya interaksi antara guru dan siswa tidak terjadi secara optimal karena hanya guru yang berperan besar dalam proses pembelajaran dan hanya guru sebagai sumber belajar. Bahkan siswa tidak termotivasi untuk memecahkan permasalahan dalam materi pembelajaran. Apabila guru menggunakan strategi yang dapat membangkitkan motivasi belajar siswa dan dapat menjadikan siswa aktif dan kreatif maka tujuan pembelajaran pasti tercapai serta hasil belajar siswa meningkat karena.guru berfungsi membantu siswa dalam pengembangan dirinya, yaitu pengembangan semua potensi, kecakapan dan karakteristik pribadinya ke arah yang positif.

Sejalan dengan persoalan di atas dalam proses pembelajaran PPKn diperlukan suatu strategi baru yang inovatif yang dapat memotivasi siswa ke arah yang lebih baik dan semangat tinggi. Dengan menggunakan strategi yang tepat maka motivasi siswa untuk belajar akan lebih meningkat dan proses pembelajaran PPKn akan lebih menarik bagi siswa.

Berdasarkan observasi yang dilakukan peneliti dengan guru kelas VIII SMP Pemda Rantauprapat pada tanggal 08 Desember 2017 bahwa tidak semua siswa memahami materi pembelajaran yang disampaikan oleh guru dengan baik. Hasil perolehan nilai ujian semester pada pelajaran PPKn di kelas VIII masih tergolong rendah, banyak siswa yang tidak mencapai nilai ketuntasan yaitu 40. Dari hasil wawancara peneliti dengan guru terlihat jelas kelemahan siswa dalam nilai ujian semester. Dari 40 orang siswa yang mengikuti ujian semester pada pelajaran PPKn hanya 8 orang siswa atau $20 \%$ yang berhasil mendapatkan nilai di atas nilai 70, sedangkan 32 orang siswa atau $80 \%$ mendapat nilai di bawah nilai 70 . Hal ini terjadi dikarenakan dalam proses pembelajaran guru belum mampu mengoptimalkan sumber dan media pembelajaran untuk membantu kegiatan pembelajaran sesuai dengan yang diharapkan.

Berdasarkan permasalahan yang dihadapi dalam proses pembelajaran PPKn diantaranya tidak tercapainya hasil belajar yang optimal maka perlu diadakan perubahan strategi pembelajaran yang akan diteliti melalui Penelitian Tindakan Kelas (PTK) sebanyak dua siklus dengan judul "Penerapan Strategi Pembelajaran Inquiry dalam meningkatkan Motivasi belajar PPKn siswa di kelas VIII SMP Pemda Rantauprapat Kabupaten Labuhanbatu Tahun Pelajaran 2017/2018. Dimana pada penelitian ini dalam proses pembelajarannya, selain menggunakan ceramah dan tanya jawab juga menggkhususkan Strategi pembelajaran Inquiri dengan dua siklus.

\section{METODOLOGI PENELITIAN Lokasi dan Waktu Penelitian}

Penelitian ini bertempat di SMP Pemda Rantauprapat di Jalan Binaraga Kecamatan Rantau Utara Kabupaten Labuhanbatu. Penelitian ini dilakukan melalui 2 siklus yakni: siklus I (tanggal 27 Januari 2018 sampai dengan 27 Februari 2018) dan siklus II (tanggal 10 maret 2018 sampai dengan 08 April 2018).

\section{Subjek Penelitian}

Subjek penelitian adalah siswa kelas VIII SMP Pemda yang terdiri dari 18 siswa laki-laki dan 22 siswa perempuan.

\section{Objek Penelitian}

Objek dalam penelitian ini adalah tindakan sebagai upaya untuk meningkatkan motivasi belajar siswa pada pelajaran PPKn.

Jenis Penelitian 
Vol. 5 NNo. 1 Juni 2018

$\mathcal{H a l}: 15-21$

Pada penelitian ini penulis menggunakan jenis penelitian tindakan kelas (PTK) yang mengarah kepada penggunaan strategi pembelajaran inquiri (belajar penemuan) untuk meningkatkan motivasi belajar siswa pada pelajaran PPKn di kelas VIII SMP Pemda Rantauprapat.

\section{Metode Pengumpulan Data}

Data-data yang diperlukan dalam penelitian ini diperoleh melalui observasi pengolahan pembelajaran dengan menggunakan Strategi pembelajaran Inquiri pada pembelajaran PPKn.

\section{Tekhnik Pengumpulan Data}

Adapun Tekhnik pengumpulan data dalam penelitian ini adalah sebagai berikut, yaitu dengan menggunakan Observasi dan angket untuk melihat motivasi belajar siswa.

\section{Teknik Analisis Data}

Adapun cara menganalisis data adalah dengan memakai analisis data persentase. Analisis persentase data ini dilakukan dengan mengetahui berhasil atau tidaknya tindakan yang dilakukan dengan menggunakan persentase sebagai berikut:

1. Nilai Perolehan Individual

Dengan rumus (Sudijono, 2008:318)

$$
P P H=\frac{B}{N} \times 100 \%
$$

2. Nilai Perolehan Klasikal

Dengan rumus (Sudijono, 2009:43)

$$
\mathrm{P}=\frac{\mathrm{f}}{\mathrm{n}} \times 100 \%
$$

Keterangan:

$\mathrm{P} \quad$ : Jumlah persentase yang mengalami perubahan

f : Jumlah siswa yang mengalami perubahan

n : Jumlah keseluruhan siswa.

Tercapainya tingkat motivasi belajar siswa mencapai $60 \%$ dari setiap siswa.
Untuk menentukan kriteria tingkat motivasi belajar siswa digunakan kriteria menurut Aqib (2006:54) sebagai berikut:

- Skor $80 \%-100 \%$ : tingkat motivasi belajar siswa tinggi

- Skor $60-79 \%$ : tingkat motivasi belajar siswa sedang

- Skor 0-59\% : tingkat motivasi belajar siswa rendah

\section{HASIL PENELITIAN DAN PEMBAHASAN Hasil Pengolahan Data}

\section{Siklus I}

a. Tahap Perencanaan

Persentase Ketuntasan Hasil Belajar Siklus I Pada kondisi awal diperoleh data bahwa 20 orang siswa $(50 \%)$ yang motivasi belajarnya tergolong rendah, 15 orang siswa $(38 \%)$ tergolong sedang, dan 5 orang siswa $(12,5 \%)$ tergolong tinggi. Motivasi belajar siswa pada kondisi awal menunjukkan bahwa siswa masih belum termotivasi dilihat dari kesulitan siswa menyelesaikan soal dan kurang memahami pokok bahasan masalah sosial di lingkungan setempat. Kesulitan itu diakibatkan:

1. Siswa kurang memahami dengan baik tentang pokok bahasan masalah sosial di lingkungan setempat

2. Siswa kurang termotivasi dalam belajar dikarenakan penggunaan metode belajar yang kurang tepat.

3. Siswa kurang memperhatikan penjelasan dari guru.

Kemudian setelah dilaksanakan perencanaan, pelaksanaan, pengamatan serta refleksi maka hasil siklus I dapat didapatkan hasilnya sebagai berikut Terdapat siswa yang mempunyai motivasi belajar rendah, sedang maupun tinggi. Motivasi belajar siswa yang tergolong rendah adalah yang mencapai persentase skor $46,3 \%$ - 59\%. Motivasi belajar siswa yang tergolong sedang adalah yang mencapai persentase skor $60 \%-75 \%$, dan motivasi belajar yang tergilong tinggi adalah mencapai persentase skor $80 \%-88 \%$. 


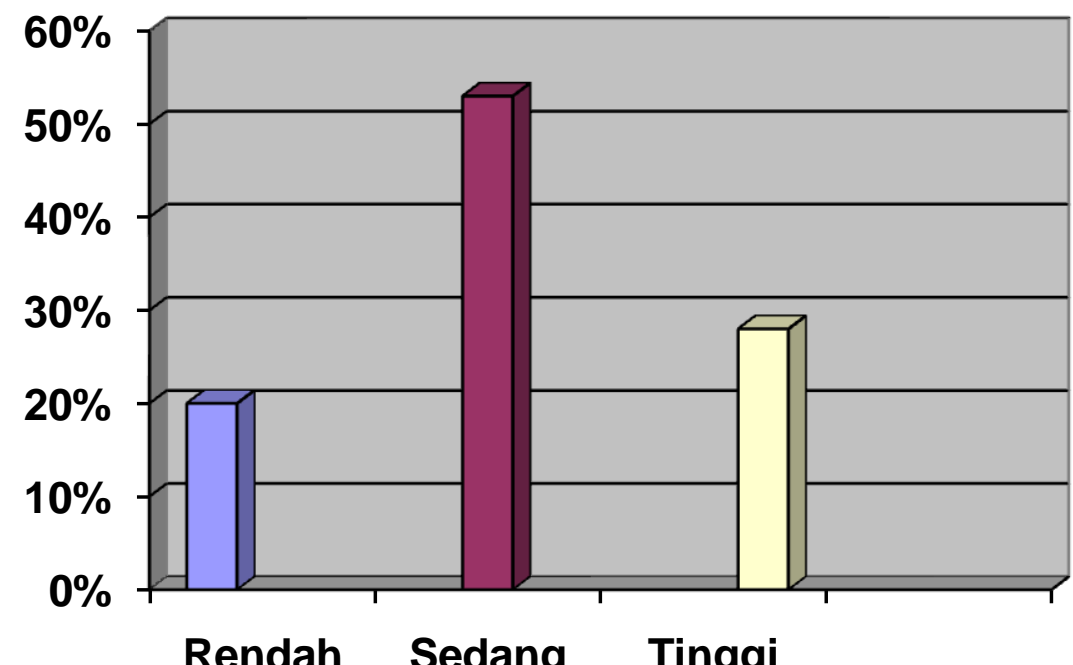

\section{$\square$ Rendah 口Sedang 口Tinggi}

Gambar 1. Persentase motivasi Belajar siswa Siklus I

Pada diagram di atas dapat dilihat motivasi siswa dalam belajar. Dari 40 orang siswa terdapat $20 \%$ siswa yang memiliki motivasi rendah, $53 \%$ siswa yang memiliki motivasi sedang dan $28 \%$ siswa yang memiliki motivasi tinggi. Dari diagram di atas dapat dilihat bahwa motivasi belajar siswa semakin meningkat.

Dari hasil analisa data I dapat ditarik kesimpulan bahwa motivasi belajar siswa dilihat dari lember angket yang telah dikerjakan siswa tergolong sedang. Hal ini dikarenakan siswa belum termotivasi sepenuhnya untuk belajar. Faktor yang menyebabkan rendahnya motivasi belajar siswa antara lain: siswa kurang memperhatikan guru ketika mengajar, siswa malu untuk mengungapkan pendapat dan siswa mudah berputus asa dalam proses pembelajaran.

\section{Siklus II}

Sebelum melaksanakan tindakan penelitian, peneliti dan guru mempersiapkan segala sesuatu yang menunjang untuk pelaksanaan tindakan penelitian. Dalam kegiatan ini mempersiapkan pokok bahasan serta strategi pembelajaran yang dapat digunakan.

Sebelum melaksanakan tindakan terlebih dahulu menerangkan materi yang akan diajarkan, yaitu berupa:

1. Mengidentifikasi masalah dan kekurangan yang terjadi pada tindakan dan motivasi belajar siswa pada siklus I

2. Memperbaiki rencana pelaksanaan pembelajaran dengan menggunakan strategi pembelajaran inquiri

3. Memberikan motivasi kepada siswa agar siswa tidak mudah putus asa.

4. Mengajak siswa untuk berani mengungkapkan pendapat

Setelah dilaksanakan penelitian

Pada Siklus II diperoleh data bahwa 2 orang siswa $(5 \%)$ yang motivasi belajarnya tergolong rendah, 4 orang siswa (10\%) tergolong sedang, dan 34 orang siswa (85\%) tergolong tinggi.

Persentase skor motivasi siswa pada siklus II dapat juga dilihat dari diagram di bawah ini: 


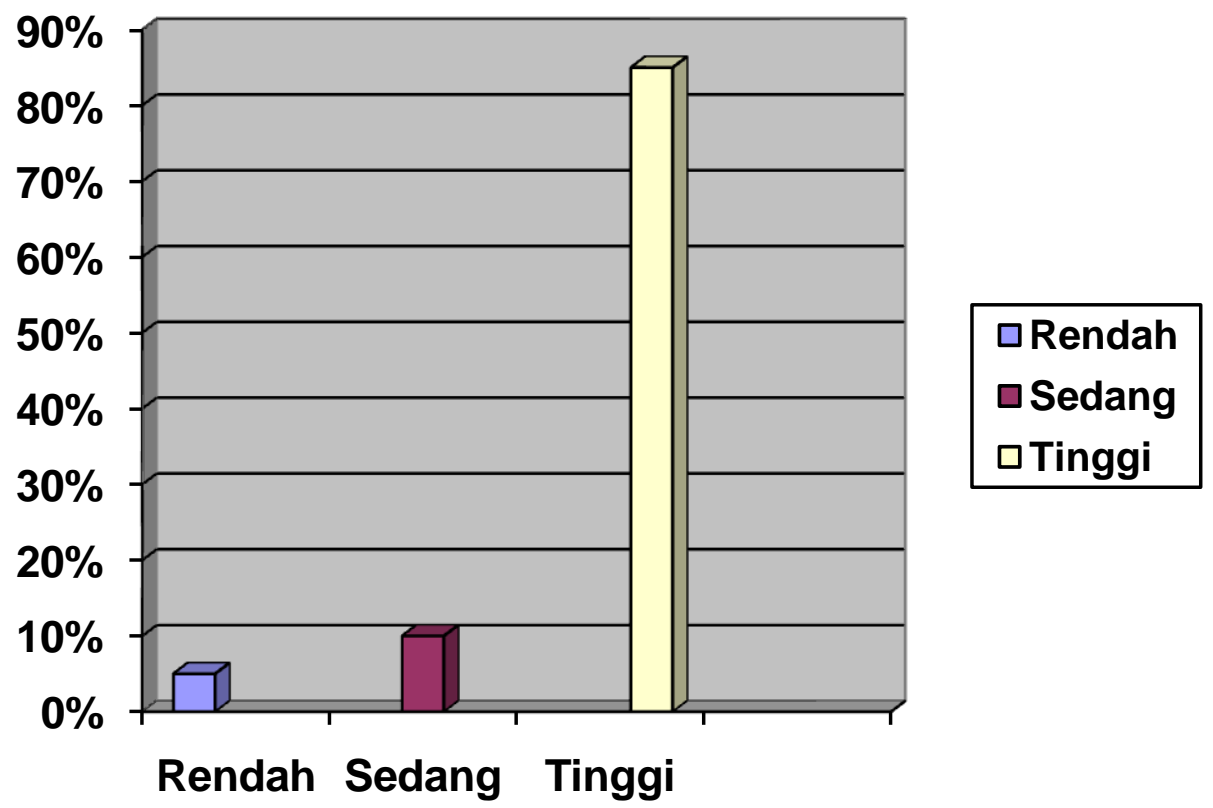

Gambar 2. Grafik Persentase Motivasi belajar siswa Siklus II

\section{Deskripsi Temuan dan Refleksi}

Berdasarkan hasil diskusi dengan teman sejawat, pembelajaran yang sudah dilaksanakan sudah berhasil. Adapun temuan dan refleksi dari hasil penelitian adalah sebagai berikut :

memperlihatkan bahwa persentase skor motivasi siswa pada kondisi awal ke siklus I dan ke siklus II meningkat. Pada siklus II dari 40 orang siswa sebanyak 34 orang siswa yang memiliki motivasi tinggi, 4 orang siswa yang memiliki motivasi sedang dan 2 orang siswa yang memiliki motivasi rendah. Pada diagram di Bawah dapat dilihat motivasi belajar siswa dari keadaan awal, siklus I dan siklus II. Keadaan awal persentase skor motivasi siswa adalah:
Pada kondisi awal dari 40 orang siswa terdapat $50 \%$ siswa yang memiliki motivasi rendah, 38\% motivasi sedang dan 12,5\% yang memiliki motivasi tinggi. Pada kondisi awal ini persentase motivasi siswa masih rendah. Pada siklus I ada peningkatan motivasi belajar siswa. Dari 40 orang siswa terdapat $20 \%$ siswa yang memiliki motivasi rendah, 53\% motivasi sedang dan 28\% yang memiliki motivasi tinggi. Pada kondisi awal ini persentase motivasi siswa masih rendah. Setelah dilakukan kembali tindakan pada siklus II persentase motivasi belajar siswa lebih meningkat. Dari 40 orang siswa terdapat $5 \%$ siswa yang memiliki motivasi rendah, $10 \%$ motivasi sedang dan $85 \%$ yang memiliki motivasi tinggi. 


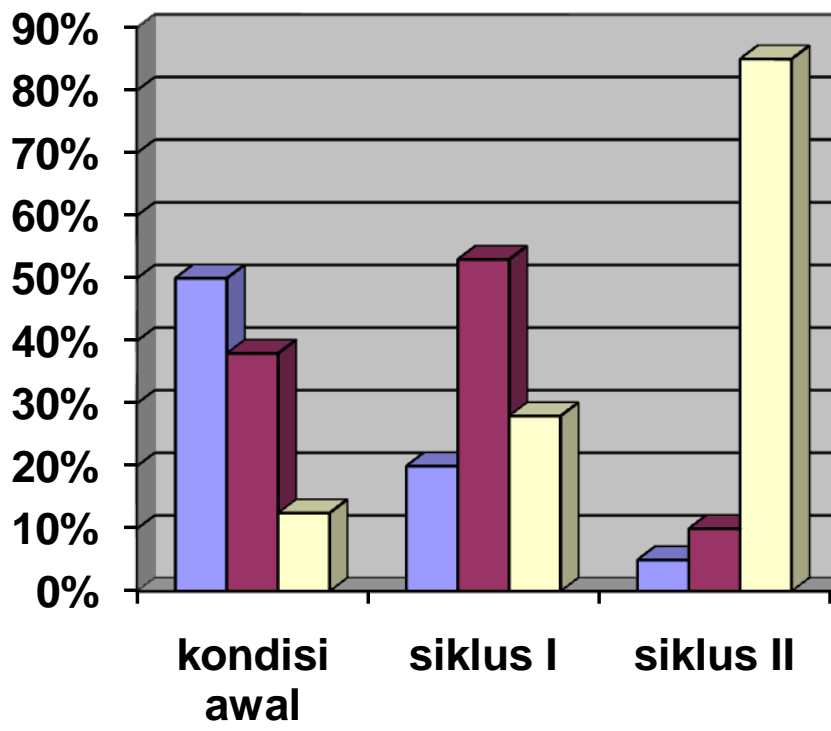

Gambar 3. Grafik Motivasi pembelajaran siswa Tes Awal, Siklus I dan Siklus II

\section{Kesimpulan}

1. Motivasi belajar siswa mengalami peningkatan setelah diberikan perlakuan dengan menggunakan strategi pembelajaran inquiri.

2. Penggunaan strategi pembelajaran inquiri dalam proses belajar mengajar dapat meningkatkan minat, motivasi dan rangsangan untuk belajar pada siswa sehingga membawa pengaruh yang positif terhadap aspek kognitifnya.

3. Strategi pembelajaran inquiri efektif diterapkan peda mata pelajaran PPKn khususnya di kelas VIII.

4. Hasil Penelitian menunjukkan bahwa pada siklus I motivasi belajar siswa adalah dengan menggunakan strategi pembelajara inquiri ini motivasi belajar siswa mengalami perubahan. Motivasi belajar siswa yang rendah $20 \%$, motivasi belajar siswa sedang $53 \%$ dan motivasi belajar siswa yang tinggi hanya 28\%. Pada siklus II didapat motivasi belajar siswa semakin meningkat. Motivasi belajar siswa yang rendah sebesar 5\%, motivasi belajar siswa yang sedang sebesar $10 \%$ dan motivasi belajar siswa tinggi sebesar $85 \%$.

5. Secara garis besar dapat disimpulkan bahwa strategi pembelajaran inquiri dapat meningkatkan motivasi belajar siswa.

\section{Saran}

Berdasarkan hasil penelitian dan pembahasan maka disarankan hal-hal berikut:

1. Guru menggunakan strategi pembelajaran inquiri untuk meningkatkan motivasi belajar siswa

2. Disarankan pula agar guru menggunakan strategi pembelajaran inquiri dalam mengajar baik pelajaran PPKn khususnya di kelas VIII

3. Disarankan kepada kepala sekolah untuk mengembangkan atau melatih para guru agar terampil menggunakan berbagai strategi pembelajaran terutama strategi pembelajaran inquiri.

4. Pada peneliti lain yang berminat disarankan untuk meneliti tentang efektivitas strategi pembelajaran inquiri dalam meningkatkan motivasi belajar siswa pada pelajaran lain di luar PPKn.

\section{DAFTAR PUSTAKA}

Arikunto, Suharsimi. 2008. Penelitian Tindakan Kelas. Jakarta: Bumi Aksara.

Aqib. 2006. Penelitian Tindakan Kelas. Bandung: Irama Widya.

Kunandar. 2007. Guru Profesional Implementasi Kurikulum Tingkat Satuan Pendidikan. Jakarta: PT Raja Grafindo Persada. 
Vol. 5 No. 1 Juni 2018

$\mathcal{H a l}: 15-21$

Bedu. 2009. Konsep Pendidikan IPS (http://beduatsuko.blogspot.com/200 9/02/makalah-konsep-pendidikanips.html diakses 6 Maret 2011)

Dimyati dan Mudjiono. 2002. Belajar dan Pembelajaran. Jakarta: Rineka Cipta. Mangkoesapoetra, A, A. 2005. Pembelajaran Pendidikan IPS di Tingkat Sekolah Dasar (http://re_searchengines.Com/080ari ef7.html, diakses 15 februari 2011)

Roestiyah. 2008. Strategi Belajar Mengajar. Jakarta: Rineka Cipta

Sagala, Syaiful. 2009. Konsep dan Makna Pembelajaran. Bandung: Alfabeta.

Sanjaya, Wina. 2009. Strategi Pembelajaran Berorientasi Standar Proses Pendidikan. Jakarta: PT Kencana Prenada Media Group.

Sardiman. 2009. Interaksi dan Motivasi Belajar Mengajar. Jakarta: PT Raja Grafindo Persada.

Sudijono, Anas. 2008. Pengantar Evaluasi Pendidikan. Jakarta: PT Raja Grafindo Persada. 